\title{
Windthrows increase soil carbon stocks in a central Amazon forest
}

\author{
Leandro T. dos Santos ${ }^{1, *}$, Daniel Magnabosco Marra ${ }^{1,2,3,{ }^{*}, \text { Susan Trumbore }}{ }^{2}$, Plínio B. de Camargo ${ }^{4}$, Robinson \\ I. Negrón-Juárez ${ }^{5}$, Adriano J. N. Lima ${ }^{1}$, Gabriel H. P. M. Ribeiro ${ }^{1}$, Joaquim dos Santos ${ }^{1}$, and Niro Higuchi ${ }^{1}$ \\ ${ }^{1}$ Laboratório de Manejo Florestal, Instituto Nacional de Pesquisas da Amazônia, Manaus, Brazil \\ ${ }^{2}$ Biogeochemical Processes Department, Max Planck Institute for Biogeochemistry, Jena, Germany \\ ${ }^{3}$ AG Spezielle Botanik und Funktionelle Biodiversität, Universität Leipzig, Leipzig, Germany \\ ${ }^{4}$ Centro de Energia Nuclear na Agricultura, Piracicaba, Brazil \\ ${ }^{5}$ Climate Sciences Department, Lawrence Berkeley National Laboratory, Berkeley, USA \\ *These authors contributed equally to this work.
}

Correspondence to: Daniel Magnabosco Marra (dmarra@bgc-jena.mpg.de)

Received: 15 September 2015 - Published in Biogeosciences Discuss.: 7 December 2015

Revised: 10 February 2016 - Accepted: 16 February 2016 - Published: 2 March 2016

\begin{abstract}
Windthrows change forest structure and species composition in central Amazon forests. However, the effects of widespread tree mortality associated with wind disturbances on soil properties have not yet been described in this vast region. We investigated short-term effects (7 years after disturbance) of widespread tree mortality caused by a squall line event from mid-January of 2005 on soil carbon stocks and concentrations in a central Amazon terra firme forest. The soil carbon stock (averaged over a $0-30 \mathrm{~cm}$ depth profile) in disturbed plots $\left(61.4 \pm 8.2 \mathrm{Mg} \mathrm{ha}^{-1}\right.$, mean $\pm 95 \%$ confidence interval) was marginally higher $(p=0.09)$ than that from undisturbed plots $\left(47.7 \pm 13.6 \mathrm{Mg} \mathrm{ha}^{-1}\right)$. The soil organic carbon concentration in disturbed plots $(2.0 \pm 0.17 \%)$ was significantly higher $(p<0.001)$ than that from undisturbed plots $(1.36 \pm 0.24 \%)$. Moreover, soil carbon stocks were positively correlated with soil clay content $\left(r^{2}=0.332, r=0.575\right.$ and $\left.p=0.019\right)$ and with tree mortality intensity $\left(r^{2}=0.257, r=0.506\right.$ and $\left.p=0.045\right)$. Our results indicate that large inputs of plant litter associated with large windthrow events cause a short-term increase in soil carbon content, and the degree of increase is related to soil clay content and tree mortality intensity. The higher carbon content and potentially higher nutrient availability in soils from areas recovering from windthrows may favor forest regrowth and increase vegetation resilience.
\end{abstract}

\section{Introduction}

Tropical forests contain about $44 \%$ (383 Pg C) of the approximately $860 \mathrm{PgC}$ stored in forests worldwide, with soils accounting for $32 \%$ of the total carbon stocks (Quere et al., 2009; Lal, 2004). Global emissions due to changes in land use and soil cultivation are estimated to be $136 \mathrm{PgC}$ since the industrial revolution (Lal, 2004; Houghton, 1999). However, there are few estimates of emissions by the decomposition and mineralization of organic carbon in soils following natural disturbances (Lal, 2004), presumably because we assume there is a balance between rapid losses that follow disturbance and recovery between disturbances at the larger spatial scales.

The effects of large-scale natural disturbances (i.e., wind disturbances) on carbon stocks and cycling due to the increase of litter inputs promoted by widespread tree mortality, the fraction of this carbon that persists in soil organic matter, and how long it is stabilized are poorly known in both in tropical and temperate forests (Foster et al., 1998; Turner et al., 1998). In temperate forests, newly exposed soil due to wind disturbance can cover from ca. $10 \%$ (Peterson et al., 1990) up to $60 \%$ of the surface (Beatty, 1980; Putz, 1983). In a three-species temperate forest in Slovakia, no organic carbon was lost at two windthrow sites within 3.5 years after disturbance, but shifts occurred within organic layers and mineral soil toward decomposed organic matter (Don et al., 2012). In Amazonian forests, where windthrows are a ma- 

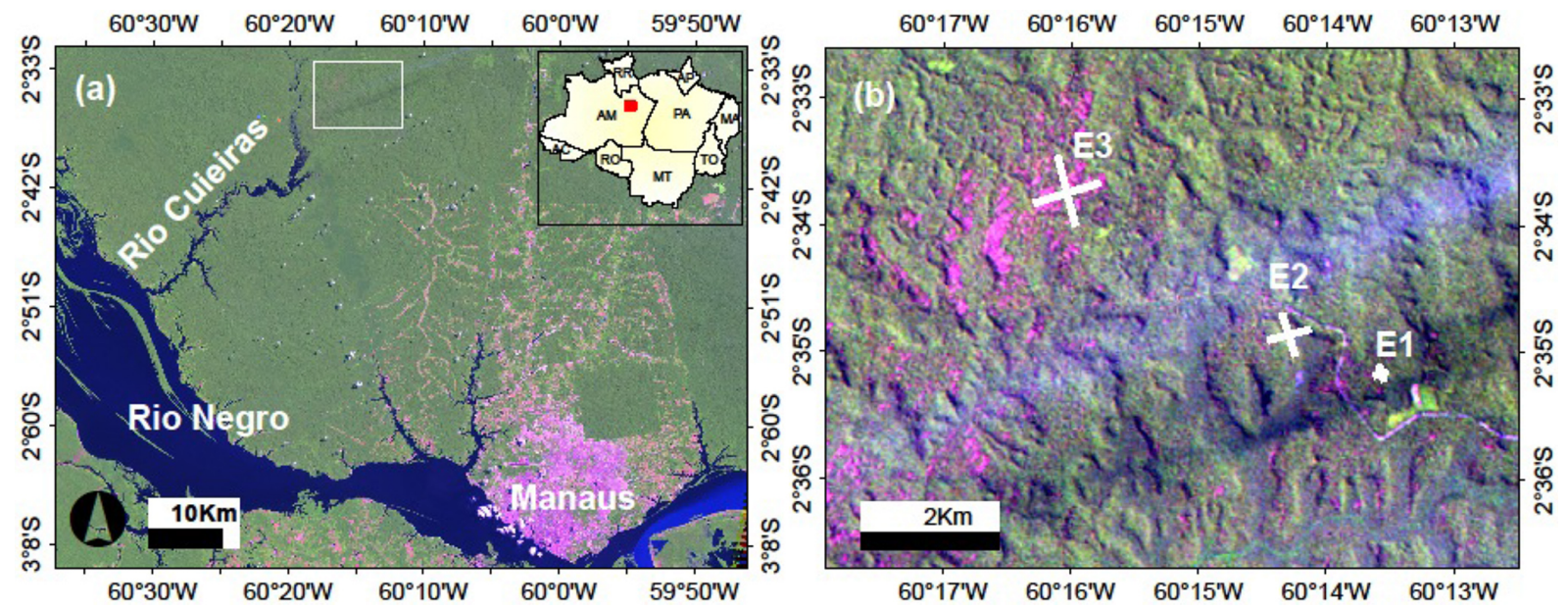

Figure 1. Study area (white inset) on the left side of the Rio Cuieiras, Amazonas, Brazil (a). Sampled transects (white inlet) set along winddisturbed terra firme forest at the Estação Experimental de Silvicultura Tropical (EEST/INPA) and a contiguous forest (SUFRAMA; b). The reddish color in (b) indicates the high middle-infrared reflectance (dead wood and litter) of wind-disturbed areas. Image: RGB composition (bands 3, 4, and 5) from Landsat 5 TM (p231, r062, from 29 July 2005). Image source: http://earthexplorer.usgs.gov/.

jor natural disturbance (Nelson et al., 1994; Chambers et al., 2013), such effects have not yet been investigated.

Wind disturbances are frequent in the western and central Amazon, (Nelson et al., 1994; Espírito Santo et al., 2010; Negrón-Juárez et al., 2010). In this large region, windthrows are associated with torrential rains and very strong winds $\left(16 \mathrm{~m} \mathrm{~s}^{-1}\right)$ known as downbursts (Nelson et al., 1994; Garstang et al., 1998). The widespread tree mortality creates canopy gaps with a wide range of sizes (from few square meters up to thousands of hectares; Nelson et al., 1994; Negrón-Juárez et al., 2010, 2011) and affects forests at the landscape level (Marra et al., 2014). It has been reported that these large gaps have a potential effect on carbon cycling (Chambers et al., 2013) and can promote tree species diversity by allowing a diverse cohort of species with a broad range of life history strategies (Chambers et al., 2009; Marra et al., 2014) and allometry (Ribeiro et al., 2014).

In the tropics, winds break and uproot trees causing strong soil disturbances (e.g., increasing leaves and wood debris and changing morphology and nutrient availability; Schaetzl et al., 1989; Lugo, 2008). Treefall gaps can also change microclimate conditions such as light intensity and create a variety of microsites, which can be separated into canopy, trunk, and root/uprooted sites (Putz, 1983). These microsites have important features that drive soil and vegetation recovery after disturbance (Putz, 1983; Schaetzl et al., 1989; Vitousek and Denslow, 1986). They can differ in microbial activity (Batjes, 1996) and enhance the colonization of fast-growing species that help in the assimilation of nutrients and soil carbon, which in turn can contribute to quickly restore the forest canopy through succession (Putz, 1983). This rapid recycling of nutrients potentially enhances the resilience of tropical forests to natural disturbances (Schaetzl et al., 1989; Ostertag et al., 2003; Lugo, 2008). However, how complex and hyperdiverse tropical forests such as the Amazon will respond in a scenario of higher frequency of extreme weather events (Coumou and Rahmstorf, 2012; Cai et al., 2014) is still not clear.

We assessed the effects of wind disturbances on soils of a large terra firme forest in central Amazon. We hypothesized that windthrows forming large canopy gaps $\left(\geq 2000 \mathrm{~m}^{2}\right)$ affect the soil carbon content via litter and wood debris deposition and decomposition, and that the soil carbon content is controlled by the interaction of tree mortality intensity, clay content, and depth. To test our hypothesis we addressed the following questions:

1. Are there differences in soil carbon stocks between disturbed and undisturbed areas, and how do possible variations compare to other tropical and temperate forests worldwide?

2. What is the importance of soil texture (clay content) on soil organic carbon content in wind disturbed areas?

3. Does tree mortality intensity influence soil carbon stocks?

\section{Methods}

\subsection{Study site}

This study was conducted in a large terra firme forest, ca. $100 \mathrm{~km}$ from Manaus, Amazonas, Brazil (Fig. 1). We sampled soils from the Estação Experimental de Silvicultura Tropical (EEST) of the Instituto Nacional de Pesquisas da Amazônia (INPA) and from a contiguous forest, adjacent to 
Table 1. Average concentrations of soil organic carbon content (SOC), soil carbon stocks (SCSs), bulk density (BD), and clay, silt, and sand average concentrations in transect 1 (E1), transect 2 (E2), and transect 3 (E3). Values in brackets represent the standard error of the mean.

\begin{tabular}{|c|c|c|c|c|c|c|c|c|c|}
\hline \multirow[b]{2}{*}{ Transect } & \multirow[b]{2}{*}{$\begin{array}{r}\text { Depth profile } \\
(\mathrm{cm})\end{array}$} & \multicolumn{2}{|c|}{ Disturbed forest } & \multicolumn{2}{|c|}{ Undisturbed forest } & \multicolumn{4}{|c|}{ Soil texture } \\
\hline & & $\begin{array}{r}\mathrm{SOC} \\
(\%)\end{array}$ & $\begin{array}{r}\text { SCS } \\
\left(\mathrm{Mg} \mathrm{ha}^{-1}\right)\end{array}$ & $\begin{array}{r}\text { SOC } \\
(\%)\end{array}$ & $\begin{array}{r}\text { SCS } \\
\left(\mathrm{Mg} \mathrm{ha}^{-1}\right)\end{array}$ & $\begin{array}{r}\text { BD } \\
\left(\mathrm{g} \mathrm{cm}^{-3}\right)\end{array}$ & $\begin{array}{r}\text { Clay } \\
(\%)\end{array}$ & $\begin{array}{l}\text { Silt } \\
(\%)\end{array}$ & $\begin{array}{r}\text { Sand } \\
(\%)\end{array}$ \\
\hline \multirow[t]{3}{*}{ E1 } & $0-10$ & $3.72(0.28)$ & $31.00(5.07)$ & $2.48(0.24)$ & $20.18(0.75)$ & 0.74 & 69.42 & 21.97 & 8.56 \\
\hline & $10-20$ & $2.31(0.13)$ & $22.82(1.97)$ & $2.05(0.22)$ & $19.24(0.74)$ & 0.97 & 69.04 & 22.42 & 8.54 \\
\hline & $20-30$ & $1.79(0.13)$ & $16.61(1.76)$ & $1.71(0.17)$ & $13.06(0.44)$ & 0.98 & 68.69 & 22.78 & 8.53 \\
\hline \multirow[t]{3}{*}{ E2 } & $0-10$ & $3.27(0.19)$ & $25.50(1.42)$ & - & - & 0.89 & 57.41 & 19.31 & 22.25 \\
\hline & $10-20$ & $1.79(0.09)$ & $19.87(0.84)$ & - & - & 1.15 & 67.59 & 22.42 & 8.54 \\
\hline & $20-30$ & $1.36(0.07)$ & $15.11(1.59)$ & - & - & 1.31 & 60.23 & 19.41 & 19.34 \\
\hline \multirow[t]{3}{*}{ E3 } & $0-10$ & $2.11(0.14)$ & $21.52(1.80)$ & $1.17(0.14)$ & $11.36(3.44)$ & 1.24 & 22.63 & 10.33 & 67.04 \\
\hline & $10-20$ & $1.31(0.08)$ & $17.48(3.08)$ & $0.82(0.09)$ & $10.69(2.63)$ & 1.36 & 57.8 & 19.1 & 23.1 \\
\hline & $20-30$ & $1.13(0.10)$ & $16.50(2.90)$ & $0.75(0.07)$ & $10.14(2.63)$ & 1.41 & 24.78 & 10.94 & 63.93 \\
\hline \multirow[t]{3}{*}{ Average } & $0-10$ & $2.89(0.13)$ & $25.90(2.06)$ & $1.58(0.19)$ & $14.90(3.18)$ & 0.95 & 50.55 & 17.30 & 32.15 \\
\hline & $10-20$ & $1.71(0.07)$ & $20.05(1.34)$ & $1.13(0.13)$ & $14.11(2.76)$ & 1.16 & 50.45 & 17.90 & 31.65 \\
\hline & $20-30$ & $1.37(0.06)$ & $16.01(1.27)$ & $0.98(0.10)$ & $11.31(1.91)$ & 1.19 & 51.95 & 17.51 & 30.54 \\
\hline
\end{tabular}

the Ramal-ZF2 road. The forest adjacent to the Ramal-ZF2 road is owned and administered by the Superintendência da Zona Franca de Manaus (SUFRAMA). Mean annual temperature in this region was $26.7^{\circ} \mathrm{C}(1910-1983$; Chambers et al., 2004), and rainfall ca. $50 \mathrm{~km}$ east of our study site averaged to $2610 \mathrm{~mm} \mathrm{yr}^{-1}$ (1980-2000; Silva et al., 2003). From July to September there is a distinct dry season with usually less than $100 \mathrm{~mm}$ of rain per month. The forest at the studied region has a closed canopy, high tree species diversity, and a dense understory (Braga, 1979).

The soils of the Amazon region are old and complex, with type and texture influenced by local topographical variations. At the studied region, the relief is undulating with altitude ranging from 40 to $180 \mathrm{~m}$ a.s.l. Soils on upland plateaus and the upper portions of slopes have high clay content (Oxisols), while soils on slope bottoms and valleys have high sand content (Spodosols; Telles et al., 2003) and are subject to sporadic inundations (Junk et al., 2011). The yellow Oxisols are found primarily on plateaus and slopes. In general, the soils are well drained and have low fertility, low $\mathrm{pH}$, low cation exchange capacity, high aluminum concentration, and low organic carbon (Ferraz et al., 1998; Telles et al., 2003).

\subsection{Tree mortality estimates}

In January of 2005, a single squall line event propagating across the Amazon caused widespread tree mortality over large areas (Negrón-Juárez et al., 2010), including ca. 250 ha of terra firme forest in the study area (Fig. 1). Tree mortality directly caused by this event was quantified at landscape level through the correlation of plot-based measurements and changes on the fractions of green vegetation $(\mathrm{GV})$ and non-photosynthetic vegetation (NPV) calculated from Landsat images - see Negrón-Juárez et al. (2010) for a detailed method description. This metric, validated by Negrón-
Juárez et al. (2011), allowed us to sample soils across an extent tree mortality gradient $0-70 \%$, including from small- to large-sized gaps and patches of old-growth forest not affected by the 2005 windthrows (Marra et al., 2014).

\subsection{Soil sampling}

We sampled soils during the dry season (July-September) of 2012 (7 years after disturbance) according to the degree of disturbance intensity measured as tree mortality (\%). In total, 16 plots with dimensions of $25 \mathrm{~m} \times 10 \mathrm{~m}$ were selected along three pairs of transects, with 200 (E1), 600 (E2), and $1000 \mathrm{~m}$ (E3) length (Fig. 1). The transects cross several toposequences and include local variations of soils and forest structure among plateaus, slopes, and valleys. In this study, we only considered plots established on plateaus, which were more severely affected by the 2005 windthrows (Marra et al., 2014). Although our samples covered soils types from Oxisols to Spodosols, we reduced strong soil attribute variations related to topography by excluding slope and valley areas.

In each of our 16 selected plots, we sampled six soil profiles $5 \mathrm{~m}$ from each other. We took samples from three depths $(0-10,10-20$, and $20-30 \mathrm{~cm})$ using an auger. For soil bulk density, samples were also collected in the three depths in one or two profiles per plot using $5 \mathrm{~cm}$ tall cylinders with a volume of $98 \mathrm{~cm}^{3}$. Altogether we collected 288 soil samples for carbon analysis ( 16 plots $\times 6$ depth profiles $\times 3$ depths) and 63 samples for density ( 21 depth profiles $\times 3$ depths; Fig. 1).

\subsection{Soil analysis}

Before performing soil analyses, we removed leaves, twigs, and roots from our samples. Samples were then sieved, dried, and homogenized by grinding $(<2 \mathrm{~mm})$. The soil carbon con- 

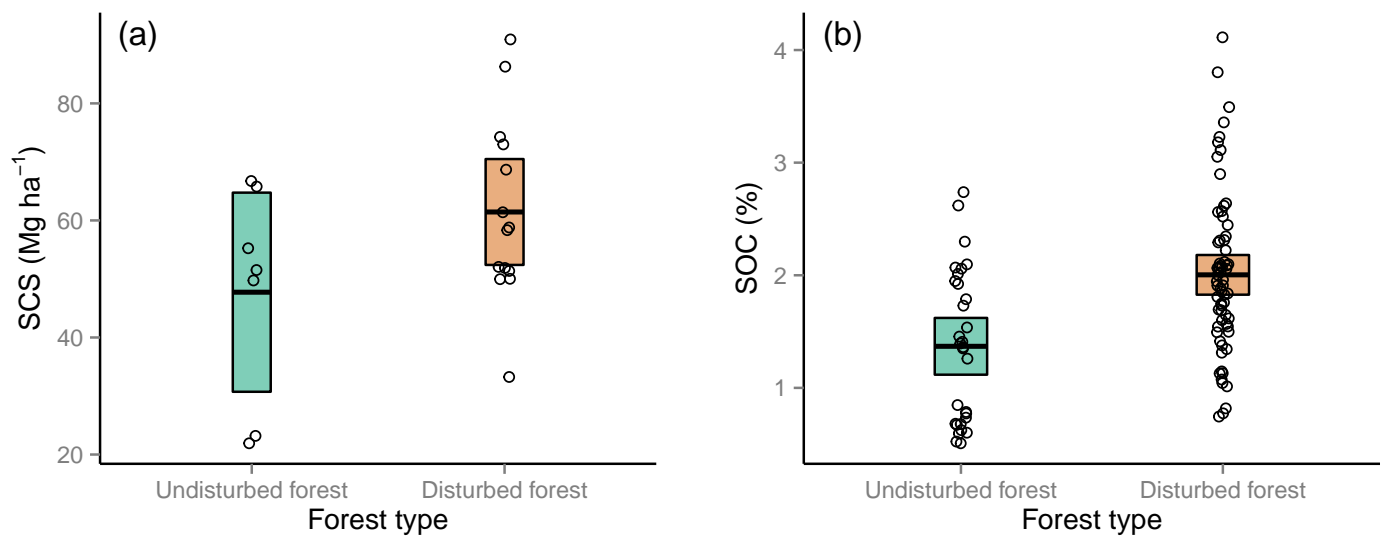

Figure 2. Comparison of the entire $0-30 \mathrm{~cm}$ depth profile for (a) soil carbon stock (SCS) and (b) soil organic carbon (SOC) between the disturbed and the undisturbed forest (mean $\pm 95 \%$ confidence interval) at $0-30 \mathrm{~cm}$ depth profile.
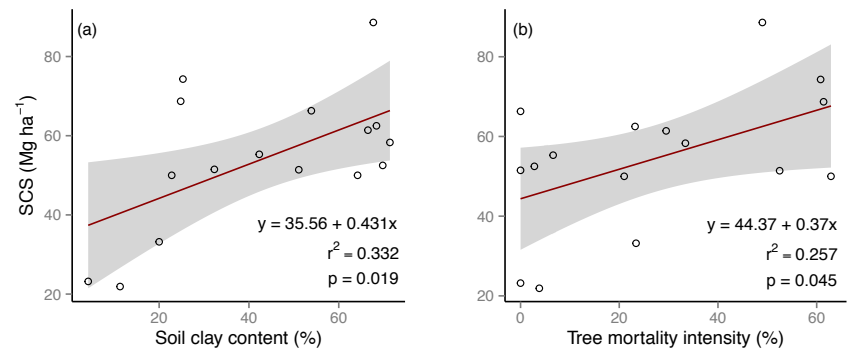

Figure 3. Soil carbon stock (SCS) as a linear function of (a) clay content (b) and tree mortality intensity $(\%)$ at $0-30 \mathrm{~cm}$ depth profile.

tent was determined in a combustion analyzer at the Centro de Energia Nuclear na Agricultura (CENA-USP), Piracicaba, Brazil. Bulk density samples were dried at $105^{\circ} \mathrm{C}$ to constant weight. The soil carbon stock (SCS; $\mathrm{Mg} \mathrm{ha}^{-1}$ ) for each depth was calculated by the formula:

$\mathrm{SCS}=(\mathrm{SOC} \times \mathrm{BD} \times D) / 10$,

where $\mathrm{SOC}$ is the soil organic carbon content $\left(\mathrm{g} \mathrm{kg}^{-1}\right)$, BD is bulk density $\left(\mathrm{g} \mathrm{cm}^{-3}\right)$, and $D$ is soil depth $(\mathrm{cm})$. The soil clay content was determined by texture analysis using the pipetting method, with data from two profiles sampled in each plot.

\subsection{Statistical analysis}

Before performing statistical tests, we tested our data set for normality and homoscedasticity. To address our first question we use factorial ANOVA and compared undisturbed/lowdisturbance plots (tree mortality $<5 \%$, hereafter referred as undisturbed forest) with those that experienced higher disturbance intensities (tree mortality $\geq 5 \%$, hereafter referred as disturbed forest). In total we sampled 5 plots in undisturbed forest and 11 plots in disturbed forest. In the disturbed forest plots were set in disturbed patches varying from $900 \mathrm{~m}^{2}$
(Landsat pixel size $(30 \times 30 \mathrm{~m})$ (Negrón-Juárez et al., 2011) to ca. 17 ha in area (Marra et al., 2014). To address our second question, we compared the SCS values from our study with those from different tropical and temperate forests. We addressed our third question using linear regression to correlate SCS to soil clay content and tree mortality intensity. We performed all analysis in R 3.0.1 platform (R Core Team, 2014) and produced Figs. 2-5 using the ggplot2 package (Wickham, 2009). We produced the Fig. 1 using the ArcMap GIS extension of the ArcGIS 10 software (ESRI, 2011).

\section{Results}

Soils from the disturbed forest had higher mean values of SCS and SOC than those from the undisturbed forest. This was true for all three depths we sampled (Table 1). SCS values averaged over $0-30 \mathrm{~cm}$ were $61.4 \pm 8.2 \mathrm{Mg} \mathrm{ha}^{-1}$ (mean $\pm 95 \%$ confidence interval) for disturbed and $47.7 \pm 13.6 \mathrm{Mg} \mathrm{ha}^{-1}$ for undisturbed forest ( $p=0.09$ and $F=3.191$; Fig. 2a). For the same depth profile, SOC values were $2.0 \pm 0.17 \%$ for the disturbed and $1.36 \pm 0.24 \%$ for the undisturbed forest $(F=16.74$ and $p<0.001$; Fig. 2b).

The soil clay content in the entire study area ranged from 2.0 to $71.5 \%$ averaged over $0-30 \mathrm{~cm}$ depth. This large variation in soil texture led to a large variation in the concentration of soil organic carbon (SOC) and soil carbon stocks (SCSs). The SOC in the upper samples $(0-10 \mathrm{~cm})$ had values ranging from 0.29 to $6.62 \%$ and mean of $2.57 \pm 0.13 \%$. For the same depth interval, values of SCS ranged from 3.79 to $48.53 \mathrm{Mg} \mathrm{ha}^{-1}$ with a mean value of $23.34 \pm 2.01 \mathrm{Mg} \mathrm{ha}^{-1}$. Overall, bulk density increased with depth, while SOC and SCS decreased (Table 1). We found no difference comparing soil clay content between the disturbed and the undisturbed forest $(F=2.648$ and $p=0.108)$. The fact that there was no difference between the two types of forest confirms 
Table 2. Estimates of soil carbon stock (SCS) from this and other studies conducted in different tropical, subtropical, and temperate forests.

\begin{tabular}{|c|c|c|c|c|c|c|}
\hline \multirow[t]{2}{*}{ Author } & \multirow[t]{2}{*}{ Region } & \multirow{2}{*}{ Forest type } & \multirow[t]{2}{*}{ Successional stage/management } & \multicolumn{2}{|c|}{$\operatorname{SCS}\left(\mathrm{Mg} \mathrm{ha}^{-1}\right)$} & \multirow[t]{2}{*}{ Soil type/description } \\
\hline & & & & $0-10 \mathrm{~cm}$ & $0-30 \mathrm{~cm}$ & \\
\hline \multirow[t]{2}{*}{ dos Santos et al. (2016) } & Manaus, AM, Brazil & Amazon terra firme forest (closed canopy) ${ }^{\mathrm{a}}$ & Undisturbed/old-growth forest & 14.9 & 47.7 & Oxisols $^{\mathrm{b}} /$ Spodosols ${ }^{\mathrm{b}}$ \\
\hline & Manaus, AM, Brazil & Amazon terra firme forest (closed canopy) & Disturbed (windthrow) forest & 25.9 & 61.4 & Oxisols/Spodosols \\
\hline \multirow[t]{4}{*}{ Telles et al. (2003) } & Manaus, AM, Brazil & Amazon terra firme forest (closed canopy) & Old-growth forest & 19.2 & & Oxisols \\
\hline & Manaus, AM, Brazil & Amazon terra firme forest (closed canopy) & Old-growth forest & 12.5 & & Spodosols \\
\hline & Floresta Nacional do Tapajós, PA, Brazil & Amazon terra firme forest (closed canopy) & Old-growth forest & 24.6 & & Oxisols \\
\hline & Floresta Nacional do Tapajós, PA, Brazil & Amazon terra firme forest (closed canopy) & Old-growth forest & 8.7 & & Ultisols $^{\mathrm{b}}$ \\
\hline Trumbore et al. (1995) & Paragominas, PA, Brazil & Amazon terra firme forest (closed canopy) & Old-growth forest & 26 & & Oxisols \\
\hline \multirow[t]{2}{*}{ Camargo et al. (1999) } & Paragominas, PA, Brazil & Amazon terra firme forest (closed canopy) & Old-growth forest & 26 & & Oxisols \\
\hline & & Amazon terra firme forest (closed canopy) & Secondary forest & 25 & & Oxisols \\
\hline Neil et al. (1996) & Ariquemes, RO, Brazil & Amazon terra firme forest (open canopy) ${ }^{a}$ & Old-growth forest & & 32.3 & Ultisols \\
\hline \multirow[t]{6}{*}{ Neill et al. (1997) } & Ariquemes, RO, Brazil & Amazon terra firme forest (open canopy) & Old-growth forest & & 27.4 & Ultisols \\
\hline & Ouro Preto do Oeste, RO, Brazil & Amazon terra firme forest (open canopy) & Old-growth forest & & 29.7 & Ultisols \\
\hline & & & Old-growth forest & & 48.1 & Ultisols \\
\hline & Porto Velho, RO, Brazil & Amazon terra firme forest (open canopy) & Old-growth forest & & 62 & Ultisols \\
\hline & Cacaulândia, RO, Brazil & Amazon terra firme forest (open canopy) & Old-growth forest & & 39.3 & Ultisols \\
\hline & Vilhena, RO, Brazil & Amazon terra firme forest (open canopy) & Old-growth forest & & 50.4 & Ultisols \\
\hline Feigl et al. (1995) & Ariquemes, RO, Brazil & Amazon terra firme forest (open canopy) & Old-growth forest & & 15.9 & Ultisols \\
\hline \multirow[t]{8}{*}{ Maia et al. (2009) } & Conquista D’Oeste, MT, Brazil & $\begin{array}{l}\text { Amazon terra firme forest (open canopy) } \\
\text { to seasonal semi-deciduous forest }\end{array}$ & Old-growth forest & & 65.3 & Oxisols \\
\hline & Guarantã do Norte, MT, Brazil & $\begin{array}{l}\text { Amazon terra firme forest (open canopy) } \\
\text { to seasonal semi-deciduous forest }\end{array}$ & Old-growth forest & & 39.3 & Ultisols \\
\hline & Nova Monte Verde, MT, Brazil & $\begin{array}{l}\text { Amazon terra firme forest (open canopy) } \\
\text { to seasonal semi-deciduous forest }\end{array}$ & Old-growth forest & & 35.4 & Oxisols \\
\hline & Pimenteiras do Oeste, RO, Brazil & Amazon terra firme forest (open canopy) & Old-growth forest & & 46.5 & Oxisols \\
\hline & & & Old-growth forest & & 33.4 & Oxisols \\
\hline & São José do Xingu, MT, Brazil & $\begin{array}{l}\text { Seasonal semi-deciduous forest to } \\
\text { Amazon terra firme forest (open canopy) }\end{array}$ & Old-growth forest & & 36.1 & Oxisols \\
\hline & Santa Luzia D’Oeste, RO, Brazil & Amazon terra firme forest (open canopy) & Old-growth forest & & 55.7 & Oxisols \\
\hline & Theobroma, RO, Brazil & Amazon terra firme forest (open canopy) & Old-growth forest & & 46.8 & Oxisols \\
\hline Maia et al. (2010) & Pontes e Lacerda, MT, Brazil & Amazon terra firme forest (closed canopy) & Old-growth forest & & 47.6 & Oxisols \\
\hline Rhoades et al. (2000) & Ecuador & Lower montane forest & Old-growth forest & & 95.6 & Andic Humitropepts \\
\hline \multirow[t]{3}{*}{ Batjes (2001) } & Senegal & Equatorial forest & Old-growth forest & & 23 & Orthic Ferralsol $^{\mathrm{c}}$ \\
\hline & & & Old-growth forest & & 35 & Plinthic Ferralsol ${ }^{\mathrm{c}}$ \\
\hline & & & Old-growth forest & & 30 & Eutric Regosol $^{\mathrm{c}}$ \\
\hline Powers and Schlesinger (2002) & Costa Rica & Tropical wet forest & Old-growth forest & 34.1 & 82.2 & $\begin{array}{l}\text { Tropohumult }{ }^{\mathrm{b}}, \text { Dystropept }^{\mathrm{b}} \\
\text { and Dystrandept }\end{array}$ \\
\hline \multirow{2}{*}{ Veldkamp et al. (2003) } & Costa Rica & Tropical moist forest & Old-growth forest & & 64 & Oxisols \\
\hline & & & Old-growth forest & & 96 & Oxisols \\
\hline Marin-Spiotta et al. (2009) & Puerto Rico & Subtropical wet forest life zone & Old-growth forest & 31 & & Oxisols \\
\hline Grimm et al. (2008) & Barro Colorado Island & Semi-deciduous moist tropical forest & Old-growth forest & 38.1 & 69.4 & Oxisols, Cambisols \\
\hline Neumann-cosel et al. (2011) & Panama & Tropical moist forest & Old-growth forest (100-year-old) & 34 & & $\begin{array}{l}\text { Homogenous, silty clay and clay, } \\
\mathrm{pH} \text { values from } 4.4 \text { to } 5.8\end{array}$ \\
\hline Ngo et al. (2013) & Singapore & Coastal hill dipterocarp forest & Old-growth forest & 22.1 & & Very acidic and infertile \\
\hline \multirow{3}{*}{ Don et al. (2012) } & Slovakia & Mixed temperate forest & Old-growth forest & ca. 47 & & Dystric Cambisols \\
\hline & & & Non-harvested windthrow (3.5-year-old) & ca. 51 & & \\
\hline & & & Harvested windthrow (3.5-year-old) & ca. 43 & & \\
\hline \multirow[t]{3}{*}{ Kramer et al. (2004) } & Tongass National Forest, Alaska, USA & Coastal temperate rain forest & Secondary forest (68-year-old) & $17^{\mathrm{d}}$ & & $\begin{array}{l}\text { Heterogeneous (Spodosols, } \\
\text { Histosols and Inceptisols) }\end{array}$ \\
\hline & & & Secondary forest (128-year-old) & $46^{d}$ & & \\
\hline & & & Secondary forest (218-year-old) & $58^{\mathrm{d}}$ & & \\
\hline \multirow[t]{2}{*}{ Huntington and Ryan (1990) } & $\begin{array}{l}\text { Hubbard Brook Experimental } \\
\text { Forest. New Hampshire, USA }\end{array}$ & Northern hardwood forest & Secondary forest (65-year-old) & 32 & & $\begin{array}{l}\text { Acidic Typic, Lithic } \\
\text { and Aquic Haplorthods }\end{array}$ \\
\hline & & & Secondary harvested forest (65-year-old) & 34 & & \\
\hline
\end{tabular}

our hypothesis that the tree mortality is the major vector of the changes we observed.

Along the entire sampled area (disturbed and undisturbed forest), the SCS was positively correlated with soil clay content (Fig. 3a) and with tree mortality intensity (Fig. 3b). When constraining the tree mortality gradient into three disturbance categories defined as tree mortality intensity $(\%)$, we found no differences in SCS $(F=1.67$ and $p=0.226$; Fig. 4a). However, SCS was $61.1 \pm 12 \mathrm{Mg} \mathrm{ha}^{-1}$ in the disturbance category 3 (tree mortality $\geq 50 \%$ ) vs. $43.1 \pm 17.2 \mathrm{Mg} \mathrm{ha}^{-1}$ in disturbance category 1 (tree mortality $<5 \%)$. The SOC in the disturbance category $2(5 \% \leq$ tree mortality $<50 \%$ ) was marginally higher than that from category 1 (Tukey HSD, $p=0.066$; Fig. 4b).

\section{Discussion}

\subsection{Estimates of soil carbon stocks}

As expected, our results were between those values found in the two soils types (Oxisols and Spodosols) evaluated in a previous study also conducted at the EEST (Telles et al., 2003), in which SCS values for $0-10 \mathrm{~cm}$ were reported as $14.9 \pm 3.18 \mathrm{Mg} \mathrm{ha}^{-1}$ (Table 2). However, the overall SCS value $\left(23.3 \pm 2.01 \mathrm{Mg} \mathrm{ha}^{-1}\right)$ and that from our disturbed forest $\left(25.9 \pm 2.06 \mathrm{Mg} \mathrm{ha}^{-1}\right)$ were greater than those reported by Telles et al. (2003). Such differences indicate an increasing in SOC and SCS 7 years following disturbance.

The soils from our study area also had different SCS values from those reported for other regions of the Brazilian Amazon (i.e., same/similar soil types; Table 2). For the 0 $10 \mathrm{~cm}$ profile, when comparing to old-growth forests in the Pará state, the mean SCSs of our undisturbed and disturbed forests were lower and similar, respectively (Trumbore et al., 

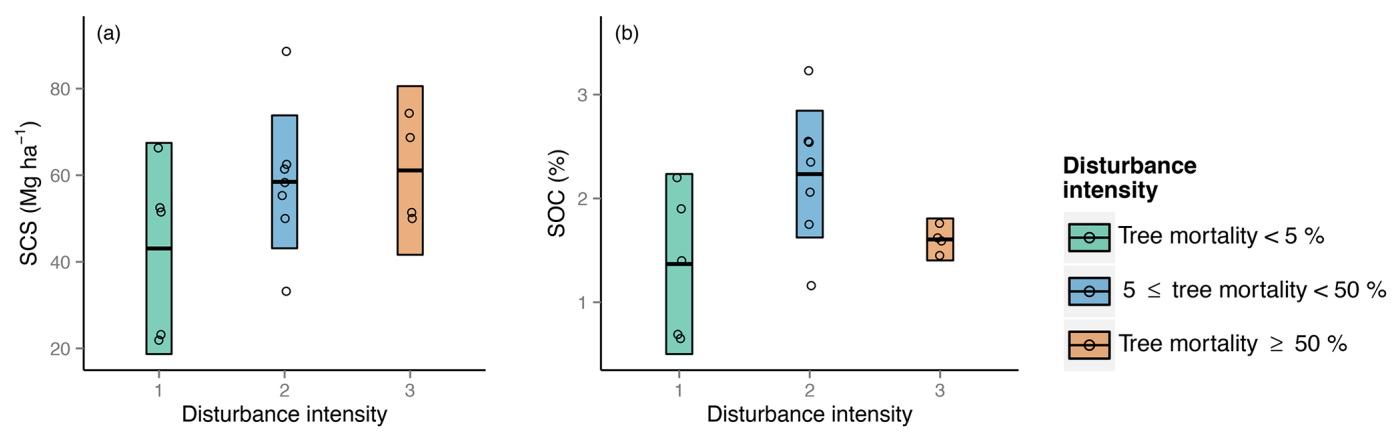

Figure 4. (a) Soil carbon stock (SCS) and (b) soil organic carbon (SOC) (mean $\pm 95 \%$ confidence interval) at $0-30 \mathrm{~cm}$ depth profile over disturbance intensity classes defined as tree mortality intensity $(\%)$.

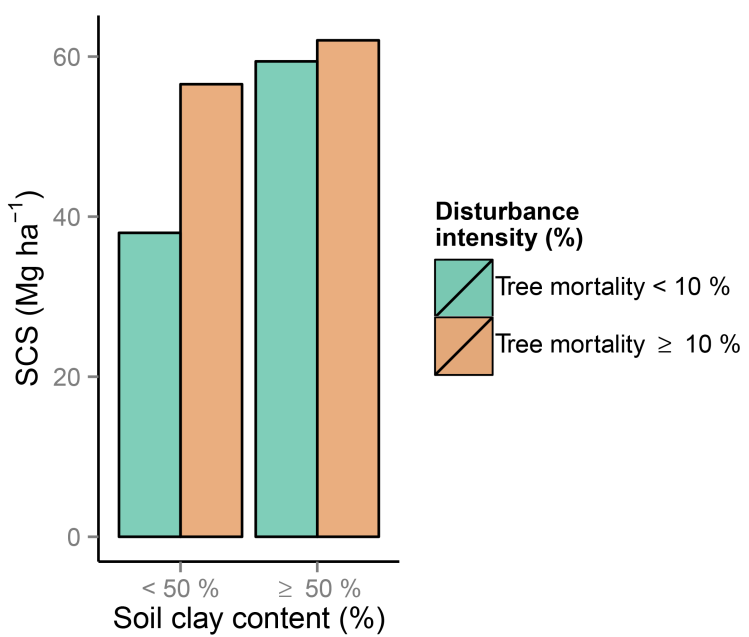

Figure 5. Soil carbon stock (SCS) at sites with different soil clay content and tree mortality intensity.

1995; Camargo et al., 1999). In the 0-30 cm depth profile, our undisturbed forest had similar SCS to that reported for other regions. When including other soil types, our disturbed forest had SCS values $\left(61.4 \mathrm{Mg} \mathrm{ha}^{-1}\right)$ higher than most reported SCS values, with the exception of SCS values reported for a region in Mato Grosso $\left(65.3 \mathrm{Mgha}^{-1}\right)$ and another in Rondônia (62 $\mathrm{Mg} \mathrm{ha}^{-1}$; Maia et al., 2009). The SCS can be influenced by soil type, texture, and mineral composition (Powers and Veldkamp, 2005; López-Ulloa et al., 2005; Neumann-Cosel et al., 2011). Indeed, the different SCS rates from different soil types are related to important factors such as geology, climate, and soil formation (Adams et al., 1990; Batjes, 1996). The differences in SCS values among our undisturbed forest and other regions in the Brazilian Amazon (as shown in Table 2) might reflect a particular geology and/or landscape variations of soil type (Quesada et al., 2010, 2011).

When comparing to forests worldwide (i.e., different soil types), both our undisturbed and disturbed forest had lower SCS values (Table 2). We only found higher SCS values than that reported for the $0-30 \mathrm{~cm}$ depth profile from an equatorial forest in Senegal, Africa (Batjes, 2001). For the 0-10 cm depth profile, our disturbed forest had SCS higher than that reported for an old-growth coastal hill dipterocarp forest in Singapore (Ngo et al., 2013) and a 68-year-old secondary coastal temperate rain forest in southeast Alaska (Kramer et al., 2004), both in different soil types. In contrast, our disturbed forest had lower SCSs than those reported for other temperate forests in Europe (Don et al., 2012) and North America (Huntington and Ryan 1990; Kramer et al., 2004). This was true for both non-harvested and harvested forests, in which nutrient exportation via logging has an opposite effect than that of wind disturbances (nutrient inputs).

\subsection{Changes in carbon stocks and clay concentration in the soil}

Soil clay content was positively correlated with the SOC (Pearson's $r=0.907$ ) at $0-30 \mathrm{~cm}$ depth profile and consequently with SCS (Pearson's $r=0.575$ ). This relationship between SOC and clay content was shown in other studies (Powers and Schlesinger, 2002; Kahle et al., 2002). The soil organic matter can form aggregates stabilizing the clay surface and the age of the soil carbon at the same depth increases with clay content (Telles et al., 2003). However, the clay content is not always a good predictor of SOC (Torn et al., 1997; Powers and Schlesinger, 2002; Telles et al., 2003). Thus, the method we applied in this study would be better applied in studies involving the same soil type and origin. In other situations, the mineralogical composition (i.e., including the type of clays) may be a better predictor of SOC than just the percentage of clay itself.

Due to the proximity of our plots, we assume climatic and geological aspects to be constant. Thus, the importance of soil texture on carbon stocks in our study site reflects a local pattern. Here we focused on assessing the effects of the existing Amazon tree mortality gradient (Espírito Santo et al., 2010; Chambers et al., 2013) on SOC and SCS, which is why we excluded valleys and selected plots along transects crossing forest patches with different disturbance inten- 
sity. Nonetheless, apart from indicating significant increase of SCS due to inputs of organic matter from tree mortality, our data show that clay-richer soils originally had higher SCS (0-30 cm depth profile) compared to soils with lower clay content (Fig. 5). Soils from areas where tree mortality was $<10 \%$ and clay content $\geq 50 \%$ had SCS ca. $36 \%$ higher than those under the same tree mortality intensity but clay content $<50 \%$ (59.4 $\mathrm{Mg} \mathrm{ha}^{-1}$ vs. $37.9 \mathrm{Mg} \mathrm{ha}^{-1}$, respectively). In contrast, where disturbance intensity was higher (tree mortality $\geq 10 \%$ ), this difference was smaller. Soils with clay content $\geq 50 \%$ had SCS only ca. $8 \%$ higher than those with clay content $<50 \%$ (62 $\mathrm{Mg} \mathrm{ha}^{-1}$ vs. $56.5 \mathrm{Mg} \mathrm{ha}^{-1}$, respectively).

This comparison confirms that the widespread tree mortality caused by the 2005 windthrows increased the SCS in our study area. A higher frequency and intensity of wind disturbances in plateau areas also suggests that the higher SCS in these portions of the relief, apart from those related to abiotic factors (e.g., soil texture, topography and erosion), might also reflect differences of vegetation dynamics. Although the soil clay content is an important aspect and greater inputs of carbon can be expected in more clayey sites, significant inputs can also occur in more sandy sites, for instance, when strong wind gusts reach lower parts of slopes and valleys.

\subsection{Intensity of disturbance and soil carbon stocks}

Although we observed an increase of SCS in areas affected by the storm, it is notable that the fresh necromass produced by widespread tree mortality events is not fully incorporated into the soil. Under this assumption, the fast decomposition of carbon stored in roots and other woody material probably contributes most to the observed increases in SCS. Carbon inputs from belowground material, which is already incorporated to the soil, might be specially related to the increase of SCS in the 10-20 and 20-30 cm depth profiles.

Seven years after the windthrow event, the SCS at $30 \mathrm{~cm}$ depth was approximately $13.7 \mathrm{Mg} \mathrm{ha}^{-1}$ greater in the disturbed forest compared to the undisturbed forest. This number is equivalent to $8.3 \%$ of the total carbon stored in the aboveground tree biomass (ca. $164 \mathrm{Mg} \mathrm{ha}^{-1}$ ) of the studied forest (Higuchi et al., 2004), which indicates an average rate of soil carbon accumulation of $1.8 \mathrm{Mg} \mathrm{ha}^{-1} \mathrm{yr}^{-1}$. Still, the amount of SCS in our disturbed forest is probably underestimated due to the large amount of carbon stored in belowground (roots) from coarse wood $>2 \mathrm{~mm}$, not included in our samples. Part of this coarse material is not incorporated into the soil. Instead, it is decomposed at the surface (Chambers et al., 2000, 2004), though some is leached into the soil or carried out by detritivores.

Amazon soils typically have a great variation in texture and nutrient availability related to physical and chemical properties (Quesada et al., 2010, 2011), which can influence basin-wide variations in forest structure and function (Quesada et al., 2012). Our results indicate that in central Amazon terra firme forests, vegetation dynamics can also influence soil attributes at the landscape level. In this region, the observed organic carbon enrichment derived from widespread tree mortality might also be related to the fast establishment and growth of pioneer species in heavily disturbed areas (Chambers et al., 2009; Marra et al., 2014).

In contrast, according to Lin et al. (2003), the Fushan Experimental Forest, which has experienced frequent windstorms, did not regain any nutrients following disturbance. This, in turn, has limited local tree growth (shown as lower canopy height) and, consequently, decreased carbon input into the soil. Thus, more intense mortality regime can also be expected to change forest dynamics, and eventually decrease SCS and nutrient cycling. The effects might depend on forest stature, successional stage (i.e., floristic composition and forest structure attributes such as tree density, basal area, and biomass), and tree mortality intensity, often controlled by the speed and duration of wind gusts (Lugo et al., 1983; Garstang et al., 1998). In our study area, fast vegetation regeneration could even reduce short-term losses of carbon associated with the 2005 windthrows, which had an estimated emission (assuming the carbon from all felled trees emitted to the atmosphere at once) of ca. $0.076 \mathrm{PgC}$, equivalent to $50 \%$ of the deforestation during that same year (Higuchi et al., 2011; Negrón-Juárez et al., 2010).

The size of gaps in which we observed significant increase on soil carbon content (gaps from 0.1 up to $17 \mathrm{ha}$ ) indicates that windthrows - apart from influencing tree species composition, forest structure, and forest dynamics (Chambers et al., 2013; Marra et al., 2014) - also change soil attributes. The nutrients released in this process might have an important feedback on vegetation resilience and recovery following disturbance. To determine how much of the added soil carbon is stabilized in a long term, future studies should assess soil carbon stocks and soil organic carbon along a chronosequence including wind-disturbed terra firme forests with different time since disturbance. Since wind is a major disturbance agent in western and central Amazon, more precise estimates of soil carbon stocks need to consider and reflect differences in tree mortality regimes at the landscape level.

Acknowledgements. We gratefully acknowledge the workers from the EEST/INPA for giving support with the fieldwork, and the lab team of the CENA-USP and the Laboratório Temático de Solos e Plantas (LTSP/INPA) for giving support with the soil analyses. We also acknowledge the SUFRAMA for allowing us to access part of the study area. At last, we acknowledge Edzo Velkamp, an anonymous referee, and Hermann F. Jungkunst for providing valuable comments during the revision of this article. This study was financed by the Conselho Nacional de Desenvolvimento Científico e Tecnológico (CNPq) within the project SAWI (Chamada Universal MCTI/N14/2012, Proc. 473357/2012-7) and the INCT - Madeiras da Amazônia. It has also been supported by the Tree Assimilation and Carbon Allocation Physiology Experiment (TACAPE), a joint project between the Biogeochemistry Processes Department of the Max Planck Institute for Biogeochemistry and the Laboratório 
de Manejo Florestal (LMF/INPA). Robinson I. Negrón-Juárez was supported by the Office of Science, Office of Biological and Environmental Research of the US Department of Energy under contract no. DE-AC02-05CH11231 as part of Next-Generation Ecosystems Experiments (NGEE Tropics) and the Regional and Global Climate Modeling (RGCM) Program.

The article processing charges for this open-access publication were covered by the Max Planck Society.

Edited by: E. Veldkamp

\section{References}

Adams, J. M., Faure, H., Faure-Denard, L., McGlade, J. M., and Woodward, F. I.: Increases in terrestrial carbon storage from the Last Glacial Maximum to the present, Nature, 348, 711-714, 1990.

Batjes, N. H.: Total carbon and nitrogen in the soils of the world, Eur. J. Soil. Sci., 47, 151-163, 1996.

Batjes, N. H.: Options for increasing carbon sequestration in West African soils: an exploratory study with special focus on Senegal, Land Degrad. Dev., 12, 131-142, 2001.

Beatty, S. W.: The role of treefalls and forest micro-topography in pattern formation in understory communities, Dissertation, Cornell University, Ithaca, New York, USA, 1980.

Braga, P. I. S.: Subdivisão fitogeográfica, tipos de vegetação, conservação e inventário florístico da floresta amazônica, Acta Amaz., 9, 53-80, 1979.

Cai, W., Borlace, S., Lengaigne, M., van Rensch, P., Collins, M., Vecchi, G., Timmermann, A., Santoso, A., McPhaden, M. J., Wu, L., England, M. H., Wang, G., Guilyardi, E., and Jin, F.: Increasing the frequency of extreme El Niño events due to greenhouse warming, Nature Climate Change, 4, 111-116, 2014.

Camargo, P. B., Trumbore, S. E., Martinelli, L. A., Davidson, E. A., Nepstad, D. C., and Victoria, R. L.: Soil carbon dynamics in regrowing forest of eastern Amazonia, Glob. Change Biol., 5, 693-702, 1999.

Chambers, J. Q., Higuchi, N., Schimel, J. P., Ferreira, L. V., and Melack, J. M.: Decomposition and carbon cycling of dead trees in tropical forests on the central Amazon, Oecologia, 122, 380388, 2000.

Chambers, J. Q., Higuchi, N., Teixeira, L. M., Santos, J., Laurance, S. G., and Trumbore, S. E.: Response of tree biomass and wood litter to disturbance in a central Amazon forest, Oecologia, 141, 596-614, 2004.

Chambers, J. Q., Robertson, A. L., Carneiro, V. M. C., Lima, A. N. L., Smith, M., Plourde, L.C., and Higuchi, N.: Hyperspectral remote detection of niche partitioning among canopy trees driven by blowdown gap disturbances in the Central Amazon, Oecologia, 160, 107-117, 2009.

Chambers, J. Q., Negrón-Juarez, R. I., Marra, D. M., Di Vittorio, A., Tews, J., Roberts, D., Ribeiro, G. H. P. M., Trumbore, S. E., and Higuchi, N.: The steady-state mosaic of disturbance and succession across an old-growth Central Amazon forest landscape, P. Natl. Acad. Sci. USA, 110, 3949-54, 2013.
Coumou, D. and Rahmstorf, S.: A decade of weather extremes, Nature Climate Change, Perspective, 2, 491-496, doi:10.1038/NCLIMATE1452, 2012.

Don, A., Bärwolff, M., Kalbitz, K., Andruschkewitsch, R., Jungkunst, H. F., and Schulze, E.: No rapid soil carbon loss after windthrow event in the High Tatra, For. Ecol. Manage., 276, 239-246, 2012.

Espírito Santo, F. D., Keller, M., Braswell, B., Nelson, B. W., Frolking, S., and Vicente, G.: Storm intensity and old-growth forest disturbances in the Amazon region, Geophys. Res. Lett., 37, 1-6, 2010.

ESRI: ArcGIS Desktop, Release 10, Redlands, CA, Environmental Systems Research Institute, 2011.

FAO: World reference base for soil resources, Rome, World Soil Resources Report, 60, 1998.

Feigl, B. J., Melillo, J., and Cerri, C. C.: Changes in the origin and quality of soil organic matter after pasture introduction in Rondônia (Brazil), Plant Soil, 175, 21-29, 1995.

Ferraz, J., Oht, S., and Salles, P. C.: Distribuição dos solos ao longo de dois transectos em floresta primária ao norte de Manaus (AM), in: Pesquisas Florestais para a Conservação da Floresta e Reabilitação de Áreas Degradadas da Amazônia, edited by: Higuchi, N., Campos, M. A. A., Sampaio, P. T. B., and dos Santos, J., Manaus, INPA, 111-143, 1998.

Foster, D., Knight, D., and Franklin, J.: Landscape Patterns and Legacies Resulting from Large, Infrequent Forest Disturbances, Ecosystems, 1, 497-510, 1998.

Garstang, M., White, S., Shugart, H. H., and Halverson, J.: Convective clouds downdrafts as the cause of large blowdowns in the Amazon Rainforest, Meteorol. Atmos. Phys., 67, 199-212, 1998.

Grimm, R., Behrens, T., Märker, M., and Elsenbeer, H.: Soil organic carbon concentrations and stocks on Barro Colorado Island, Digital soil mapping using Random Forests analysis, Geoderma, 146, 102-113, 2008.

Higuchi, N., Chambers, J. Q., Santos, J., Ribeiro, R. J., Pinto, A. C. M., Silva, R. P., Rocha, R. M., and Tribuzi, E. S.: Dinâmica e balanço do carbono da vegetação primária da Amazônia Central, Floresta, 34, 295-304, 2004.

Higuchi, N., Santos, J., Lima, A. J. N., Higuchi, F. G., and Chambers, J. Q. A.: A floresta amazônica e a água da chuva, Floresta, 41, 427-434, 2011.

Houghton, R. A.: The annual net flux of carbon to the atmosphere from changes in land use 1850-1990, Tellus, 50B, 298-313, 1999.

Huntington, T. G. and Ryan, D. F.: Whole-tree-harvesting effects on soil nitrogen and carbon, For. Ecol. Manage., 31, 193-204, 1990.

IBGE: Mapa de vegetação do Brasil, Fundação Instituto Brasileiro de Geografia e Estatística/ Ministério da Agricultura/ Instituto Brasileiro de Desenvolvimento Florestal, IBGE, Rio de Janeiro, 2004.

Junk, W., Piedade, M., Shongärt, J., Cohn-Haft, M., Adeney, J., and Wittmann, F.: A classification of major naturally-occurring amazonian lowland wetlands, Wetlands, 31, 623-640, 2011.

Kahle, M., Kleber, M., Torn, M. S., and Jahn, R.: Carbon storage in coarse and fine clay fractions of illitic soils, Soil Sci. Soc. Am. J., 67, 1732-1739, 2002. 
Kramer, M. G., Sollins, P., and Sletten, R. S.: Soil carbon dynamics across a windthrow disturbance sequence in southeast Alaska, Ecology, 85, 2230-2244, 2004.

Lal, R.: Soil carbon sequestration to mitigate climate change, Geoderma, 123, 1-22, 2004.

Lin, K., Hamburg, S. P., Tang, S., Hsia, Y., and Lin, T.: Typhoon effects on litterfall in a subtropical forest, Can. J. Forest. Res., 33, 2184-2192, 2003.

López-Ulloa, M., Veldkamp, E., and de Koning, G. H. J.: Soil carbon stabilization in converted tropical pastures and forests depends on soil type, Soil Sci. Soc. Am. J., 69, 1110-1117, 2005.

Lugo, A. E., Applefield, M., Pool, D., and Mcdonald, R.: The impact of Hurricane David on the forests of Dominica. Can. J. Forest. Res., 13, 201-211, 1983.

Lugo, A. E.: Visible and invisible effects of hurricanes on forest ecosystems: an international review, Austral Ecol., 33, 368-398, 2008.

Maia, S. M. F., Ogle, S. M., Cerri, C. E. P., and Cerri, C. C.: Effect of grassland management on soil carbon sequestration in Rondônia and Mato Grosso states, Brazil, Geoderma, 149, 84-91, 2009.

Maia, S. M. F., Ogle, S. M., Cerri, C. C., and Cerri, C. E. P.: Changes in soil organic carbon storage under different agricultural management systems in the Southwest Amazon Region of Brazil, Soil Till. Res., 106, 177-184, 2010.

Marin-Spiotta, E., Silver, W. L., Swanston, C. W., and Ostertag, R.: Soil organic matter dynamics during 80 years of reforestation of tropical pastures, Glob. Change Biol., 15, 1584-1597, 2009.

Marra, D. M., Chambers, J. Q., Higuchi, N., Trumbore, S. E., Ribeiro, G. H. P. M., Santos, J. dos, Negrón-Juarez, R. I., Reu, B., and Wirth, C.: Large-Scale Wind Disturbances Promote Tree Diversity in a Central Amazon Forest, PLoS ONE 9, e103711, doi:10.1371/journal.pone.0103711, 2014.

Negrón-Juarez, R. I., Chambers, J. Q., Guimarães, G., Zeng, H., Raupp, C. F. M., Marra, D. M., Ribeiro, G. H. P. M., Saatchi, S., Nelson, B. W., and Higuchi, N.: Widespread Amazon forest tree mortality from a single cross-basin squall line event, Geophys. Res. Lett., 37, 1-5, 2010.

Negrón-Juárez, R. I., Chambers, J. Q., Marra, D. M., Ribeiro, G. H. P. M., Rifai, S. W., Higuchi, N., and Roberts, D.: Detection of subpixel treefall gaps with Landsat imagery in Central Amazon forests, Remote Sens. Environ., 115, 3322-3328, 2011.

Neil, C., Fry, B., Melillo, J. M., Steudler, P. A., Moraes, J. F. L., and Cerri, C. C.: Forest- and pasture-derived carbon contributions to carbon stocks and microbial respiration on tropical pasture soils, Oecologia, 107, 113-119, 1996.

Neill, C., Melillo, J. M., Steudler, P. A., Cerri, C. C., de Moraes, J. F. L., Piccolo, M. C., and Brito, M.: Soil carbon and nitrogen stocks following forest clearing for pasture in the southwestern Brazilian Amazon, Ecol. Appl., 7, 1216-1225, 1997.

Nelson, B. W., Kapos, V., Adams, J. B., Oliveira, W. J., and Oscar, P. G. B.: Forest Disturbance by Large Blowdowns in the Brazilian Amazon, Ecol. Soc. Am., 75, 853-858, 1994.

Neumann-Cosel, L., Zimmermann, B., Jefferson, S., van Breugel, M., and Helmut, E.: Soil carbon dynamics under young tropical secondary forests on former pastures - A case study fom Panama, Forest Ecol. Manag., 261, 1625-1633, 2011.

Ngo, K. M., Turner, B. L., Muller-Landau, H. C., Davies, S. J., Larjavaara, M., Hassan, N. F. bin N., Lum, S.: Carbon stocks in pri- mary and secondary tropical forests in Singapore, Forest Ecol. Manag., 296, 81-89, 2013.

Ostertag, R., Scatena, F. N., and Silver, W. L.: Forest floor decomposition following hurricane litter inputs in several Puerto Rican forests, Ecosystems, 6, 261-273, 2003.

Peterson, C. J., Carson, W. P., McCarthy, B. C., and Pickett, S. T. A.: Microsite variation an soil dynamics within newly created treefall pits and mounds, OIKOS, 58, 39-46, 1990.

Powers, J. S. and Schlesinger, W. H.: Relationships among soil carbon distributions and biophysical factors at nested spatial scales in rain forests of northeastern Costa Rica, Geoderma, 109, 165190, 2002.

Powers, J. S. and Veldkamp, E.: Regional variation in soil carbon and $\delta^{13} \mathrm{C}$ in forests and pastures of northeastern Costa Rica, Biogeochemistry, 72, 315-336, 2005.

Putz, F. E.: Treefall pits and mounds, buried seeds, and the importance of soil disturbance to pioneer trees on Barro Colorado Island, Panama, Ecology, 64, 1069-1074, 1983.

Queré, C. L., Raupach, M. R., Canadell, J. G., and Marland, G.: Trends in the sources and sinks of carbon dioxide, Nat. Geosci., 2, 831-836, 2009.

Quesada, C. A., Lloyd, J., Schwarz, M., Patiño, S., Baker, T. R., Czimczik, C., Fyllas, N. M., Martinelli, L., Nardoto, G. B., Schmerler, J., Santos, A. J. B., Hodnett, M. G., Herrera, R., Luizão, F. J., Arneth, A., Lloyd, G., Dezzeo, N., Hilke, I., Kuhlmann, I., Raessler, M., Brand, W. A., Geilmann, H., Moraes Filho, J. O., Carvalho, F. P., Araujo Filho, R. N., Chaves, J. E., Cruz Junior, O. F., Pimentel, T. P., and Paiva, R.: Variations in chemical and physical properties of Amazon forest soils in relation to their genesis, Biogeosciences, 7, 1515-1541, doi:10.5194/bg-7-15152010, 2010.

Quesada, C. A., Lloyd, J., Anderson, L. O., Fyllas, N. M., Schwarz, M., and Czimczik, C. I.: Soils of Amazonia with particular reference to the RAINFOR sites, Biogeosciences, 8, 1415-1440, doi:10.5194/bg-8-1415-2011, 2011.

Quesada, C. A., Phillips, O. L., Schwarz, M., Czimczik, C. I., Baker, T. R., Patiño, S., Fyllas, N. M., Hodnett, M. G., Herrera, R., Almeida, S., Alvarez Dávila, E., Arneth, A., Arroyo, L., Chao, K. J., Dezzeo, N., Erwin, T., di Fiore, A., Higuchi, N., Honorio Coronado, E., Jimenez, E. M., Killeen, T., Lezama, A. T., Lloyd, G., López-González, G., Luizão, F. J., Malhi, Y., Monteagudo, A., Neill, D. A., Núñez Vargas, P., Paiva, R., Peacock, J., Peñuela, M. C., Peña Cruz, A., Pitman, N., Priante Filho, N., Prieto, A., Ramírez, H., Rudas, A., Salomão, R., Santos, A. J. B., Schmerler, J., Silva, N., Silveira, M., Vásquez, R., Vieira, I., Terborgh, J., and Lloyd, J.: Basin-wide variations in Amazon forest structure and function are mediated by both soils and climate, Biogeosciences, 9, 2203-2246, doi:10.5194/bg-9-2203-2012, 2012.

R Core Team: R: A language and environment for statistical computing, available at: http://www.r-project.org (last access: 1 October 2015), 2014.

Rhoades, C. C., Eckert, G. E., and Coleman, D. C.: Soil carbon differences among forest, agriculture, and secondary vegetation in lower montane Ecuador, Ecol. Appl., 10, 497-505, 2000.

Ribeiro, G. H. P. M., Suwa, R., Marra, D. M., Lima, A. J. N., Kajimoto, T., Ishizuka, M., and Higuchi N.: Allometry for Juvenile Trees in an Amazonian Forest after Wind Disturbance, JARQJpn. Agr. Res. Q., 48, 213-219, 2014. 
Schaetzl, R. J., Burns, S. F., Johnson, D. L., and Small, T. W.: Tree uprooting: review of impacts on forest ecology, Vegetatio, 79, 165-176, 1989.

Silva, R. P. da, Nakamura, S., Azevedo, C. de, Chambers, J., Rocha, R. de M., Pinto, C., dos Santos, J., and Higuchi, N.: Use of metallic dendrometers for individual diameter growth patterns of trees at Cuieiras river basin, Acta Amaz., 33, 67-84, 2003.

Telles, E. de C. C., Camargo, P. B. de, Martinelli, L. A., Trumbore, S. E., Costa, E. S. da, Santos, J. dos, Higuchi, N., and Oliveira Jr., R. C.: Influence of soil texture on carbon dynamics and storage potential in tropical forest soils of Amazonia, Global Biogeochem. Cy., 17, 1040, doi:10.1029/2002GB001953, 2003.

Torn, M. S., Trumbore, S. E., Chadwick, O. A., Vitousek, P. M., and Hendricks, D. M.: Mineral control of soil organic carbon storage and turnover, Nature, 389, 3601-3603, 1997.

Trumbore, S. E., Davidson, E. A., De Camargo, P. B., Nepstad, D. C., and Martinelli, L. A.: Belowground cycling of carbon in forests and pastures of Eastern Amazonia, Global Biogeochem. Сy., 9, 515-528, 1995.
Turner, M., Baker, W., Peterson, C., and Peet, R.: Factors influencing succession: lessons from large, infrequent natural disturbances, Ecosystems, 1, 511-523, 1998.

Veldkamp, E., Becker, A., Schwendenmann, L., Clark, D. A., and Schulte-Bisping, H.: Substantial labile carbon stocks and microbial activity in deeply weathered soils below a tropical wet forest, Glob. Change Biol., 9, 1171-1184, 2003.

Vitousek, P. M. and Denslow, J. S.: Nitrogen and phosphorous availability in treefall gaps of a lowland tropical rainforest, J. Ecol., 74, 1167-1178, 1986.

Wickham, H.: ggplot2: elegant graphics for data analysis, Springer New York., 2009. 